Primljen / Received: 31.7.2015.

Ispravljen / Corrected: 24.12.2015.

Prihvaćen / Accepted: 18.1.2016.

Dostupno online / Available online: 10.2.2016.

\section{Models for estimating uniaxial} compressive strength and elastic modulus

Authors:

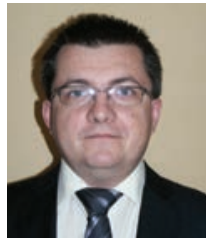

Zlatko Briševac, PhD. Min.

University of Zagreb

Faculty of Mining, Geology and Petroleum

Engineering

zlatko.brisevac@rgn.hr

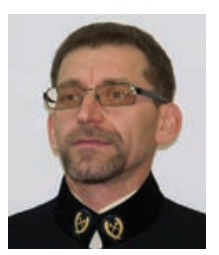

Assist.Prof. Petar Hrženjak, PhD. Min.

University of Zagreb

Faculty of Mining, Geology and Petroleum

Engineering

petar.hrzenjak@rgn.hr

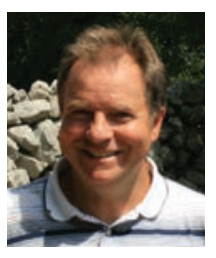

Renato Buljan, PhD. Geol.

Croatian Geological Surveyt

renato.buljan@hgi-cgs.hr

\section{Zlatko Briševac, Petar Hrženjak, Renato Buljan}

Subject review

\section{Models for estimating uniaxial compressive strength and elastic modulus}

The most significant methods for estimating the uniaxial compressive strength and Young's modulus of intact rock material, formulated in the scope of numerous previous studies, are briefly presented in the paper. The proposal for classification of these methods, according to which they can generally be divided into simple and complex methods, is also presented. Simple methods include various diagrams and tables and the use of simple regression equations, while complex methods comprise the use of multiple regression equations, fuzzy logic models, neural networks, evolutionary programming, and regression trees.

Key words:

estimation, uniaxial compressive strength, Young's modulus, intact rock material

Pregledni rad

Zlatko Briševac, Petar Hrženjak, Renato Buljan

\section{Modeli za procjenu jednoosne tlačne čvrstoće i modula elastičnosti}

U ovom radu ukratko je izložen pregled najznačajnijih metoda za procjenu jednoosne tlačne čvrstoće i Yangovog modula elastičnosti intaktnog stijenskog materijala koje su nastale u okviru mnogobrojnih istraživanja. Iznesen je prijedlog podjele metoda prema kojemu se one u osnovi mogu podijeliti na jednostavne i složene metode. Jednostavne metode uključuju različite dijagrame i tablice te primjenu jednadžbi jednostruke regresije, a složene metode uključuju primjene jednadžbi višestruke regresije, modela neizrazite logike, neuronskih mreža, evolucijskog programiranja i regresijskog stabla.

Ključne riječi:

procjena, jednoosna tlačna čvrstoća, Yangov modul elastičnosti, intaktni stijenski materijal

Übersichtsarbeit

Zlatko Briševac, Petar Hrženjak, Renato Buljan

\section{Modelle zur Bewertung der einachsigen Druckfestigkeit und des} Elastizitätsmoduls

In dieser Arbeit wird ein Überblick der wichtigsten Methoden zur Bewertung der einachsigen Druckfestigkeit und Young's Elastizitätsmodul, die im Rahmen zahlreicher Untersuchungen entstanden sind, bei intaktem Felsmaterial gegeben. Es wird ein Vorschlag zur Aufteilung in einfache und komplexe Methoden gegeben. Einfache Methoden umfassen verschiedene Diagramme und Tabellen, sowie die Anwendung von Einzelregressionsgleichungen. Komplexe Methoden beziehen sich auf die Anwendung von Mehrfachregressionsgleichungen, Modelle der Fuzzy-Logik, neuronale Netze, evolutionäre Programmierung und Regressionsbäume.

Schlüsselwörter:

Bewerung, einachsige Druckfestigkeit, Young's Elastizitätsmodul, intaktes Felsmaterial 


\section{Introduction}

Various investigations are normally carried out both in the scope of construction projects, and for making other technical interventions in the rock mass. These investigations routinely include realization of laboratory tests aimed at determining physicomechanical properties of intact rock material. At that, and in addition to the density of materials, one of the most often defined properties is the uniaxial compressive strength (UCS), and the Young's modulus of elasticity (E). However, it often occurs that samples of the dimensions required for laboratory testing can not be extracted from such materials. That is why the need arose already at early stages of development of rock mechanics to determine the correlation of various physicomechanical properties of materials, so that one property can be estimated based of the value of another one. These interdependencies have proven to be very useful in preliminary stages of the planning and design activities. Many researchers have studied the possibility for estimating the UCS and E values based on values of other material properties. Although simple interdependencies were used in the beginning, current estimation methods are proving to be increasingly complex.

\section{Estimate models}

\subsection{Tables and diagrams}

In simplest cases, the UCS estimation can be made according to an index test based on the method recommended by the International Society for Rock Mechanics, as presented in Table 1. This table also contains useful additions made by Marinos and Hoek [1]. In this case, the estimate is made using portable equipment (nail, knife, geological hammer) and an appropriate description is given as shown in Table 1. The strength index determined by point load test can assist in this estimate.

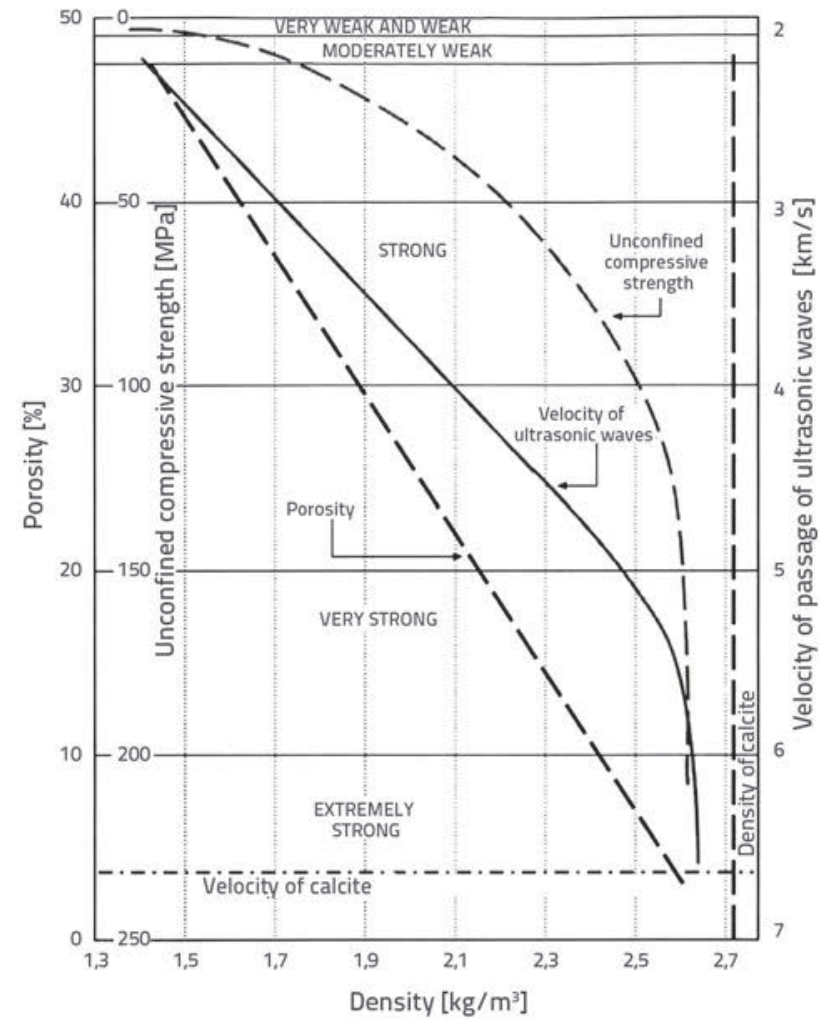

Figure 1. UCS as related to porosity and velocity of ultrasonic waves for limestones, [2]

Diagrams can also be quite useful in situations requiring rapid decision making. The diagram showing interdependence between the density, porosity and velocity of ultrasound waves

Table 1. Determination of uniaxial compressive strength by hand held accessories

\begin{tabular}{|c|c|c|c|c|c|}
\hline Grade & Description & UCS & $I_{s(50)}$ & Field identification & Rock types \\
\hline R6 & $\begin{array}{l}\text { Extremely } \\
\text { strong rock }\end{array}$ & $>250$ & $>10$ & $\begin{array}{l}\text { Specimen can only be pull apart by a geological } \\
\text { hammer }\end{array}$ & $\begin{array}{l}\text { fresh basalt, chert, diabase, } \\
\text { gneiss, granite, and quartzite }\end{array}$ \\
\hline R5 & $\begin{array}{l}\text { Very strong } \\
\text { rock }\end{array}$ & $100-200$ & $4-10$ & $\begin{array}{l}\text { Specimen requires many blows of geological hammer } \\
\text { to fracture it. }\end{array}$ & $\begin{array}{l}\text { amphibiolite, sandstone, } \\
\text { basalt, gabbro, gneiss, } \\
\text { granodiorite, limestone, } \\
\text { marble, rhyolite, and tuff }\end{array}$ \\
\hline R4 & Strong rock & $50-100$ & $2-4$ & $\begin{array}{l}\text { Specimen requires more than one blow by geological } \\
\text { hammer to fracture it. }\end{array}$ & $\begin{array}{l}\text { limestone, marble, sandstone, } \\
\text { and schist }\end{array}$ \\
\hline R3 & $\begin{array}{l}\text { Medium } \\
\text { strong rock }\end{array}$ & $25-50$ & $1-2$ & $\begin{array}{l}\text { Cannot be scraped or peeled with a pocket knife; } \\
\text { specimen can be fractured with a single firm blow of a } \\
\text { geological hammer. }\end{array}$ & phyllite, schist, siltstone \\
\hline $\mathrm{R} 2$ & Weak rock & $5-25$ & - & $\begin{array}{l}\text { Can be peeled by a pocket knife with difficulty; shallow } \\
\text { indentations made by firm blow with a point of } \\
\text { geological hammer. }\end{array}$ & $\begin{array}{l}\text { chalk, rock salt, claystone, marl, } \\
\text { siltstone, schist }\end{array}$ \\
\hline R1 & Weak rok & $1-5$ & - & $\begin{array}{l}\text { Crumbles under firm blows with point of geological } \\
\text { hammer; can be peeled by pocket knife }\end{array}$ & $\begin{array}{l}\text { highly weathered or altered } \\
\text { rock, schist }\end{array}$ \\
\hline Ro & $\begin{array}{l}\text { Extremely } \\
\text { weak rock }\end{array}$ & $0,25-1$ & - & Indented by thumbnail. & stiff fault gouge \\
\hline
\end{tabular}


(Figure 1), presented by Price [2], can be used to make a rough estimate of the UCS value of limestone material.

The best known diagram for the relationship between $E$ and UCS is the one presented by Deere and Miller [3] (Figure 2).

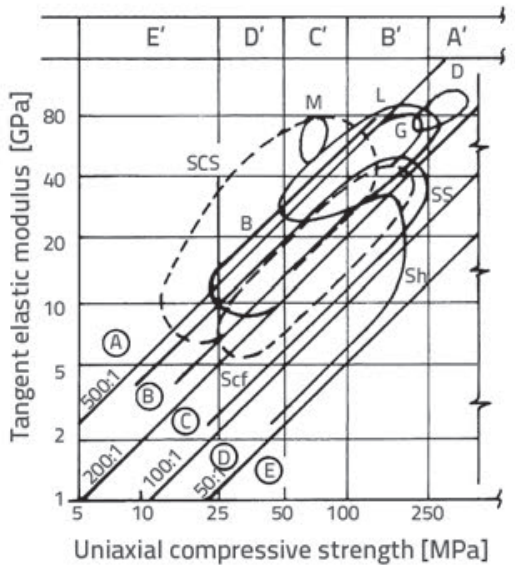

$$
\begin{aligned}
& \text { A' - very high strength } \\
& B^{\prime} \text { - high strength } \\
& C^{\prime} \text { - medium strength } \\
& D^{\prime} \text { - low strength } \\
& \mathrm{E}^{\prime} \text { - very low strength } \\
& \mathrm{B} \text { - basalt G - granite } \\
& \mathrm{L} \text { - limestone } \mathrm{D} \text { - dolomite } \\
& \text { Sh - shale M - marble } \\
& \text { SS - sandstone } \\
& \text { Scf - schist with flat foliation } \\
& \text { SCS - schist with steep foliation } \\
& \text { (A) - Very high modulus ratio } \\
& \text { (B) - High modulus ratio } \\
& \text { (C) - Average modulus ratio } \\
& \text { (D) - Low modulus ratio } \\
& \text { (B) - Very low modulus ratio }
\end{aligned}
$$

Figure 2 UCS to E ratio, [3]

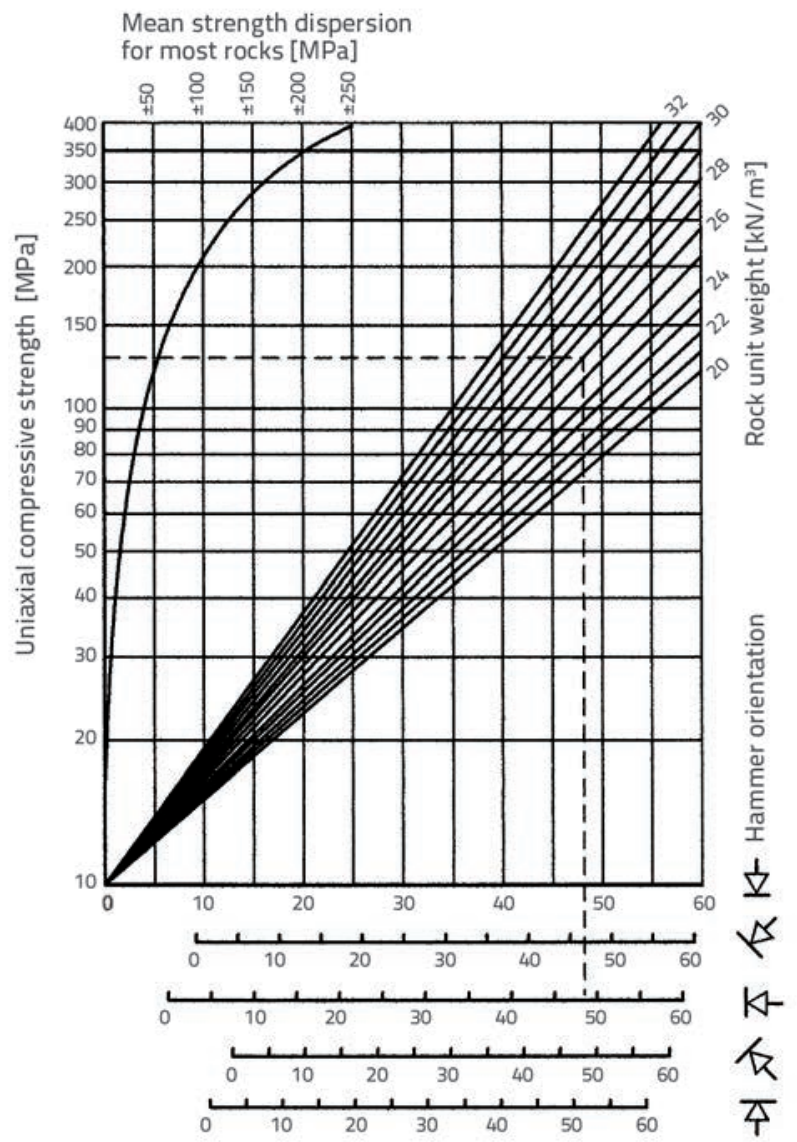

Figure 3. Schmidt hardness and UCS ratio, [4]

The diagram published in Miller's dissertation [4] (Figure 3) can be used to estimate the UCS value of intact rock based on the Schmidt hardness (SRH) and unit weight of rock, regardless of

\begin{tabular}{|c|c|c|}
\hline Equation & Type of rock & Authors \\
\hline$U C S=15,3 I_{S(50)}+16,3$ & all rocks & $\begin{array}{l}\text { D'Andrea, and ost., } \\
\text { 1964. [11] }\end{array}$ \\
\hline$U C S=16 I_{S(50)}$ & $\begin{array}{l}\text { sedimentary } \\
\text { rocks }\end{array}$ & $\begin{array}{l}\text { Read et all., } 1980 . \\
{[12]}\end{array}$ \\
\hline UCS $=(20$ to 25$) I_{S(50)}$ & all rocks & ISRM, 1985. [13] \\
\hline UCS $=(\operatorname{od} 14,5$ do 27$) \mathrm{I}_{\mathrm{S(50)}}$ & limestone & $\begin{array}{l}\text { Romana, } 1999 . \\
\text { [14] }\end{array}$ \\
\hline UCS $=24,4 \mathrm{I}_{\mathrm{S}(50)}$ & hard rocks & \multirow{2}{*}{$\begin{array}{l}\text { Quane and Russel, } \\
\text { 2003. [15] }\end{array}$} \\
\hline$U C S=3,86 I_{S(50)}{ }^{2}+5,65 I_{S(50)}$ & weak rocks & \\
\hline UCS $=7,3 I_{S(50)}^{1,71}$ & $\begin{array}{l}\text { limestone, } \\
\text { sandstone, marl }\end{array}$ & $\begin{array}{l}\text { Tsiambaos and } \\
\text { Sabatakakis, } 2004 . \\
\text { [16] }\end{array}$ \\
\hline$U C S=24,8 I_{S(50)}-39,6$ & rocks with $n<1 \%$ & \multirow{2}{*}{$\begin{array}{l}\text { Kahraman and ost. } \\
\text { 2005. [17] }\end{array}$} \\
\hline$U C S=10,2 I_{S(50)}+23,4$ & rocks with $n>1 \%$ & \\
\hline$U C S=10,58 I_{S(50)}{ }^{1,14}$ & all rocks & \multirow{4}{*}{$\begin{array}{l}\text { Tsallas and ost., } \\
\text { 2009. [18] }\end{array}$} \\
\hline UCS $=10,46 I_{S(50)}^{1,12}$ & $\begin{array}{l}\text { sedimentary } \\
\text { rocks }\end{array}$ & \\
\hline UCS $=6,65 I_{S(50)}{ }^{1,34}$ & igneous rocks & \\
\hline$U C S=18,15 I_{S(50)}$ & $\begin{array}{l}\text { metamorphic } \\
\text { rocks }\end{array}$ & \\
\hline
\end{tabular}
rock type that is being tested.

\subsection{Simple regression equations}

Simple regression equations comprise relations defined for the estimation of UCS and E values as dependent variables based on the tested value of another property that constitutes an independent variable. Various equations for estimating UCS and $\mathrm{E}$ values have been defined by regression analysis based on results obtained by testing physicomechanical properties of intact rock materials. Thus, for instance, Table 2 shows equations presented by various authors for some rock types, where UCS and E values are estimated based on a known porosity value.

Table 2. Uniaxial regression equations with porosity

\begin{tabular}{|l|l|l|}
\hline Equation & Type of rock & Authors \\
\hline UCS $=183-16,55 n$ & granite & Turgul and Zarif, 1999. [5] \\
\hline UCS $=74,4 \mathrm{e}^{-0,04 \mathrm{n}}$ & sandstone & Palchik, 1999. [6] \\
\hline $\mathrm{E}=10,10-0,109 \mathrm{n}$ & porous rocks & Leite and Ferland, 2001. [7] \\
\hline $\begin{array}{l}\mathrm{UCS}=210,1 \mathrm{e}^{-0,821 \mathrm{n}} \\
\mathrm{E}=37,9 \mathrm{e}^{-0,863 \mathrm{n}}\end{array}$ & $\begin{array}{l}\text { shale, claystone, } \\
\text { siltstone }\end{array}$ & Lashkaripour, 2002. [8] \\
\hline UCS $=273,1 \mathrm{e}^{-0,076 n}$ & porous chalk & Palchik and Hatzor, 2004. [9] \\
\hline UCS $=195,0 \mathrm{e}^{-0,21 \mathrm{n}}$ & sandstone & Tugrul, 2004. [10] \\
\hline $\begin{array}{l}\text { UCS - unconfined compressive strength [MPa]; E- elastic modulus [GPa]; } \\
\mathrm{n} \text { - porosity [\%] }\end{array}$ & \multicolumn{2}{|l}{} \\
\hline
\end{tabular}

Table 3. Simple regression equations with strength index 
The determination of strength index $I_{s(50)}$ by point load test is an index test that has been developing from the very start for the very purpose of estimating the UCS value, so that there are many papers in which the corresponding equations are published. The most significant equations for estimating the UCS value of various rocks similar to those found in Croatia are presented in Table 3.

It should be noted with regard to Table 3 that exponential equations are more accurate than linear-form equations for almost all rock types, except for metamorphic rocks where linear equation has proven to be slightly more accurate [18]. Other than the strength index, the hardness of materials determined by Schmidt hammer has also often been used in these estimations. For instance, the UCS and E values can be successfully estimated based on Schmidt hardness. Some examples of equations developed for this purpose are presented in Table 4. Local experience in the UCS and E estimation [19], gained during intensive motorway infrastructure development in Croatia, when 518 boreholes over $7000 \mathrm{~m}$ in total length were analysed, reveal that the dependence between the UCS and Schmidt hardness greatly deviates in $[4,20,21]$ from correlations presented in this paper.

Table 4. Simple regression equations with Schmidt hardness

\begin{tabular}{|c|c|c|}
\hline Equation & Type of rock & Authors \\
\hline $\begin{array}{l}\text { UCS }=4,29 \text { SRH }-67,52 \\
E=1,94 \text { SRH }-33,93\end{array}$ & 33 limestone types & $\begin{array}{l}\text { Sachpazis, } 1990 \\
{[20]}\end{array}$ \\
\hline $\begin{array}{l}\text { UCS }=2,21 e^{(0,075 R H)} \\
E=0,00013 S R H^{3,09}\end{array}$ & $\begin{array}{l}\text { chalk, two } \\
\text { limestone types, } \\
\text { sandstone, marble, } \\
\text { syenite, granite }\end{array}$ & $\begin{array}{l}\text { Katz and ost., } \\
\text { 2000. [21] }\end{array}$ \\
\hline $\begin{array}{l}\text { UCS }=\mathrm{e}^{(0,818+0,0595 \mathrm{SH})} \\
E=\mathrm{e}^{(1,146+0,054 \mathrm{SRH})}\end{array}$ & gypsum & $\begin{array}{l}\text { Yilmaz and Sendir, } \\
\text { 2002. [22] }\end{array}$ \\
\hline $\begin{array}{l}\text { UCS }=0,0028^{\text {SRH } 2,584} \\
E=0,0987^{S R H} 1,5545\end{array}$ & $\begin{array}{l}\text { travertine, } \\
\text { limestone, } \\
\text { dolomitic limestone } \\
\text { and schist }\end{array}$ & Yagiz, 2009. [23] \\
\hline
\end{tabular}

Table 5. Simple regression equations with $\mathrm{P}$-wave velocities

\begin{tabular}{|l|l|l|}
\hline Equation & Type of rock & Authors \\
\hline UCS $=9,95 v_{p}^{1,21}$ & $\begin{array}{l}\text { dolomite, sandstone, } \\
\text { marl, limestone, } \\
\text { diabase, serpentinite }\end{array}$ & $\begin{array}{l}\text { Kahraman, 2001. } \\
{[24]}\end{array}$ \\
\hline $\begin{array}{l}\text { UCS }=31,5 v_{p}-63,7 \\
E=10,67 v_{p}-18,71\end{array}$ & $\begin{array}{l}\text { dolomite, marble } \\
\text { and limestone }\end{array}$ & $\begin{array}{l}\text { Yasar and Erdogan, } \\
\text { 2004. [25] }\end{array}$ \\
\hline$E=2,06 v_{p}^{2,78}$ & $\begin{array}{l}\text { limestone, marble } \\
\text { and sandstone }\end{array}$ & $\begin{array}{l}\text { Moradian and } \\
\text { Behnia, 2009. [26] }\end{array}$ \\
\hline $\begin{array}{l}\text { UCS - uniaxial compressive strength [MPa]; E- elastic modulus [GPa]; } \\
v_{p}-\text { P-wave velocity [km/s] }\end{array}$
\end{tabular}

In addition, the study of velocity of passage of ultrasonic $p$-waves $\left(v_{p}\right)$ through samples of various materials has enabled establishment of various ratios, and hence also of simple regression equations that are shown in Table 5.

Simple regression equations that were used to estimate the UCS and E values were linear and nonlinear in form. It was established that better estimates were obtained with nonlinear forms such as general power equations or exponential equations. It should be noted that simple regression models are often evaluated in research papers through correlation coefficients and/or coefficients of determination. Almost ideal values have been obtained by some authors, and so the coefficients of determination for E and UCS amount to as much as 0.99 [21] and 0.98 [22], respectively. This can however be misleading as the use of more rigorous estimation methods such as the adjusted $\mathrm{R}^{2}$, root mean square error (RMSE), Akaike information criterion, or cross-validation, would certainly show that the models are in fact not so ideal. Practical usability of a model where complex sample preparation is required for the independent variable determination, such as in $\mathrm{V}_{\mathrm{p}}$ determination, is questionable.

\subsection{Multiple regression equations}

The multiple linear regression is generally presented with equation (1):

$Y=\beta_{0}+\beta_{1} X_{1}+\beta_{2} X_{2}+\ldots+\beta_{k} X_{k}+\varepsilon$

where is:

$Y \quad$ - dependent variable

$X_{1}, X_{2}, \ldots, X_{k}$ - independent variables

$\beta_{i} \quad$ - denotes contribution of the independent variable $X_{i}$

$\varepsilon \quad-$ random error [27].

The linear form of the multiple regression equation completely dominates in models for estimation of the UCS and E values. Similarly, multiple regression models are predominantly developed for comparison with models based on other methods. Models presented below are the models made for rock material similar to that prevailing in Croatia, and the UCS estimation is given in MPa, while $\mathrm{E}$ is determined in GPa.

Thus Alvarez Grimaa and Babuška [28] prepared a multiple regression model (2) based on test results for materials classified as sandstones, limestones, dolomites, granites, and granodiorites. The multiple regression model is presented as follows:

UCS $=-246,804+0,386$ Ls $+39,268 \rho-1,307 n$

where is:

Ls - hardness defined with the Equotip hardness tester

$\rho$ - density $\left[\mathrm{kg} / \mathrm{m}^{3}\right]$

$n$ - porosity [\%]. 
A similar model (3) created by testing the same rock types was developed by Meulenkamp and Alvarez Grima [29]. This model is presented with the following equation:

UCS $=0,25$ Ls $+28,14 \rho-0,75 n-15,47$ GS $-21,55$ RT

where is:

Ls - hardness defined with the Equotip hardness tester

$\rho$ - density $\left[\mathrm{kg} / \mathrm{m}^{3}\right]$

n - porosity [\%]

GS - grain size

RT - rock type.

Gokceoglu and Zorlu [30] prepared multiple regression models (4) and (5) for weak, fractured, and thin-bedded rocks that are represented with the following expressions:

$\mathrm{UCS}=-225+0,0065 \mathrm{v}_{\mathrm{P}}+1,468 \mathrm{BPI}+4,094 \mathrm{I}_{\mathrm{S}(50)}+2,418 \mathrm{TS}$

$E=-0,038+0,003 v_{p}+0,892 B P I+3,568 I_{S(50)}$

where is:

$\mathrm{V}_{\mathrm{p}} \quad$-ultrasonic velocity of P-waves [m/s]

$\mathrm{BPI}$ - block punch strength index [MPa]

$\mathrm{I}_{\mathrm{S}(50)}$ - strength index defined by the point load test [MPa]

TS - tensile strength [MPa]

Karakus and Tutmez [31] developed the UCS estimation model (6) based on the testing of marble, limestone and dacite originating from Malatya and Elazig regions in Turkey. This model is represented as follows:

UCS $=-35,9+0,89 S R H+13,1 I_{S(50)}-1,68 v_{p}$

where is:

$\mathrm{SRH}$ - Schmidt hardness

$\mathrm{I}_{\mathrm{S}(50)}$ - strength index defined by the point load test [MPa]

$v_{p} \quad$ - velocity of ultrasound waves [ $\left.\mathrm{km} / \mathrm{s}\right]$.

Kahraman et al [32] developed the models (7) and (8) for tectonic breccias. These models are represented with the following expressions:

UCS $=-35,09-0,33 \mathrm{VBP}+35,38 \mathrm{v}_{\mathrm{S}}$

$E=-103,88-0,16 V B P+39,65 \rho+4,2 v_{P}+4,33 v_{s}$

where is:

VBP - the volume percent of fragments [\%]

$\rho$ - density $\left[\mathrm{kg} / \mathrm{m}^{3}\right]$

$v_{S}$ - velocity of ultrasonic S-waves [km/s]

$v_{p}$ - velocity of ultrasonic P-waves [km/s].

Yilmaz and Yuksek developed the models (9) and (10) for natural gypsum [33]
UCS $=-23,859+0,48 S R H+1,863 I_{S(50)}+0,248 w+7,972 v_{p}$

$E=36,315+0,64 S R H+2,254 I_{S(50)}+0,935 w+12,838 v_{p}$

where is:

SRH - Schmidt hardness

$\mathrm{I}_{\mathrm{S}(50)}$ - strength index defined by the point load test [MPa]

w - water content [\%]

$v_{p} \quad$-velocity of ultrasonic P-waves [km/s].

Based on the analysis of limestones, marbles, and dolomites from Iran, Heidari et al [34] developed a nonlinear multiple regression model (11) for the estimation of $E$ value. This model is represented with the following expression:

$$
\begin{aligned}
\log E= & -0,85448+0,91326 \log \text { UCS }+0,03198 \log n \\
& +0,16123 \log v_{p}-0,22327 \log \rho
\end{aligned}
$$

where is:

UCS -uniaxial compressive strength [MPa]

n - porosity [\%].

$v_{p} \quad$ - velocity of ultrasonic Pp-waves $[\mathrm{km} / \mathrm{s}]$

$\rho \quad$ density $\left[\mathrm{kg} / \mathrm{m}^{3}\right]$.

Using the most influential petrographic properties of materials, Manouchehrian et al developed the model (12) for estimating the UCS of sandstone [35]. The model is represented with the following expression:

$U C S=38-352,26 n-5,3 C_{f c}+10,6 C_{f}+93,15 M_{p}$

where is:

$n$ - porosity [\%].

$\mathrm{C}_{\mathrm{fc}}$ - ferrous carbonate binder percentage [\%]

$\mathrm{C}_{\mathrm{f}}$ - percentage of iron oxide in cement [\%]

$\mathrm{M}_{\mathrm{p}}$ - percentage of mica [\%].

Equations for estimating the UCS (13) and E (14) values which use, as independent variables, the frequently determined physicomechanical properties, were developed based on testing conducted on 29 types of carbonate rock materials from 19 localities in the Republic of Croatia.

$$
\begin{aligned}
\text { UCS }= & -222+0,0535 \rho+0,7801 n+13,76 I_{S(50)} \\
& +1,752 \text { SHRL }+0,0061 v_{p} \\
E= & -182+0,0619 \rho+0,7228 n-0,459 I_{S(50)} \\
& +0,5907 \text { SHRL }+0,0073 v_{p}
\end{aligned}
$$

where is:

$\rho$ - density $\left[\mathrm{kg} / \mathrm{m}^{3}\right]$

$n$ - porosity [\%].

$\mathrm{I}_{S(50)}$ - strength index defined by the point load test [MPa]

$\mathrm{SRH}$-Schmidt hardness

$v_{p} \quad$ - velocity of ultrasonic P-waves [m/s]. 
The equations (15) and (16) were developed for the mudstone and wackestone type limestones originating from Croatia [37].

$$
\begin{aligned}
& \text { UCS }=-106,2093-0,04868 \rho+11,5110 I_{S(50)}+0,052 v_{p} \\
& \text { UCS }=-240,0109+1,5087 n+11,5916 I_{S(50)}+0,0522 v_{p}
\end{aligned}
$$

where is:

$$
\begin{array}{ll}
\rho & \text { - density }\left[\mathrm{kg} / \mathrm{m}^{3}\right] \\
\mathrm{n} & \text { - porosity [\%] } \\
\mathrm{s}_{S(50)} & \text { - strength index defined by the point load test [MPa] } \\
v_{\mathrm{P}} & \text { - velocity of ultrasonic P-waves [m/s]. }
\end{array}
$$

It can be seen from the above presented multiple regression models that researchers mostly used physicomechanical properties as independent variables, while petrographic properties of rock material were less often used. It is interesting to note that the density and porosity are used together as independent variables in the models (2), (3), (11), (13), and (14) although, due to great physical connection of these properties, it can not be claimed that these variables are independent from one another, as is required by the mathematical model of multiple regression.

\subsection{Models based on fuzzy logic analysis}

In the traditional "crisp" logic, a rational claim can be either true or false. According to fuzzy logic, no claim is fully true or fully false, but rather a "level of truthfulness" can be attributed to it. Rules have been set for using this logic, and these rules are a generalisation of normal Boolean algebra [38]. Although fuzzy logic was initially used in social sciences, it is now increasingly used in technical sciences as well, e.g. in risk management on construction projects [39], but also in various evaluations. Most significant and the most often used models based on fuzzy logic and fuzzy reasoning are the Mamdani and Sugeno models.

Based on Mamdani model, Gokceoglu and Zorlu developed a model for estimation of USC and $E$ values based on the input values similar to those used in models (4) and (5) [30]. The same type of fuzzy model was used by Karakus and Tutmez for development of the UCS estimation model. The investigation was made for nine different rock types and for a total of 305 samples. The input data for the model were laboratory testing results as in model (6) [31]. By comparing fuzzy model with the multiple regression model, these researchers concluded that a better UCS estimation is obtained by using the fuzzy model [30, 31]. Alvarez and Babuska developed the UCS estimation model using theoretical premises from TakagiSugeno model based on results of testing involving 226 intact rock material samples classified as sandstones, limestones, dolomites, granites and granodiorites. Input data were the same as independent variables from equation (2). Estimation results were compared with the multiple regression modelling results, and also with the results obtained via neural network that was established using the same input data. It was concluded that better estimation was obtained by fuzzy model compared to multiple regression model, while the neural network provided better estimation than fuzzy model for low and high UCS values [28]. Subsequent development of programming techniques resulted in the situation in which fuzzy models were not often developed on their own, but rather the fuzzy logic became a part of other methods, e.g. in neural networks.

\subsection{Estimation by neural networks}

Neural networks consist of the systems of input and output values constituting nodes or neurons and the links or synapses between them, through which attempts are made to artificially simulate the way the human brain functions. In most cases, neural networks are not realised as hardware systems but rather as software programs, i.e. using the programming code. Neural networks are not programmed as algorithms with accurately determined relationships, but rather as algorithms capable of learning through examples. They are presented with examples and solutions to these examples, and algorithms can then automatically generate empirical rules. Before such algorithms can be used for estimating certain values, computer programs have to be "trained" on as set of known and required values [38]. Neural networks are increasingly used for solving various problems and tasks in many areas and so, for instance, they are used in civil engineering in the design of timber structures [40], in water management [41], determination of liquefaction potential [42], design of railway embankments [43], etc.

The possibility of estimating UCS and E values using neural networks was analysed during study of carbonate rocks from 19 localities in the Republic of Croatia, from which a total of 425 samples were taken and tested in laboratory to determine their density, porosity, strength index, Schmidt hardness, UCS, and E. Thirteen multiple regression models and 65 neural networks type MLP (multilayer perceptron) and RBF (radial basis function) were developed in the program package Statistica 10. An extensive scientific literature was analysed in the scope of this research [36]. Due to a great number of neural network types presented by various authors, there are several possible ways for classifying neural networks for various areas of application. The authors of this paper consider, based on their experience, that the most appropriate is the simplified modification of the Gupta and Rao classification [44] (Figure 4), which primarily starts from the analysis of artificial neural networks used in the estimation of UCS and E values, which is presented in paper [36].

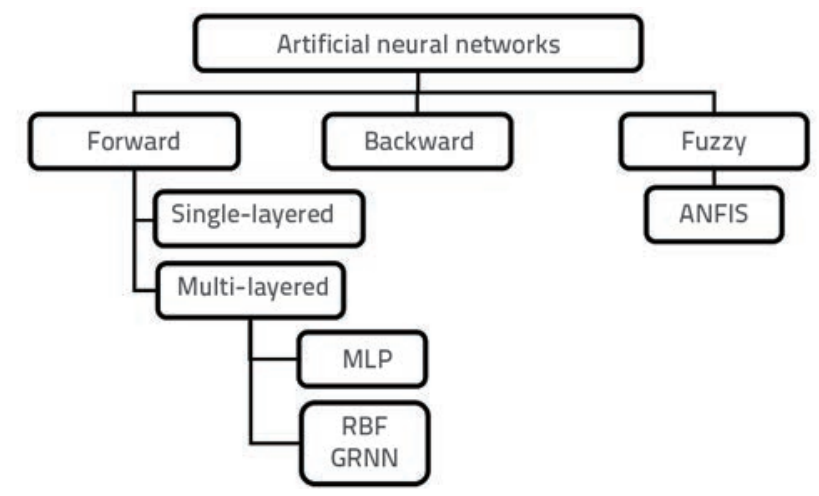

Figure 4. Classification of neural networks 
Meulenkamp and Alvarez developed the UCS estimation model based on the feedforward neural network in which the output error back propagation algorithm was used for training. Input values used in this model are similar to those used in model (3). The network was "trained" using the Levenberg-Marquardt algorithm [29]. Sonmeza et al described the use of artificial neural networks in the estimation of $E$ value for different rock types, based on the input values of UCS and material density [45]. Kahraman et al used neural networks in the estimation of the UCS and E values for tectonic breccias. In the UCS estimation model, the neural network was structured as 2-3-1 (number of inputs, number of neurons in the hidden layer, output value). The network input was formed of the volume part of fragments and the velocities of ultrasonic S-waves. The network of the model developed for estimating the $E$ value was structured as 4-3-1, and the input was formed of: volume part of fragments, density, velocity of ultrasonic S-waves, velocity of ultrasonic P-waves, roundness of fragments, and the average grain size factor [32]. The use of fuzzy neural networks in the estimation of UCS and E for natural gypsum was described by Yilmaz and Yuksek. Input parameters for the model were the following values obtained by laboratory testing: Schmidt hardness, strength index based on point load test, water content, and velocity of ultrasonic P-waves. The network was formed using the ANFIS systems and the program packages Matlab Version 7.1 and SPSS 10.0. After comparison of results, these authors concluded that the best results in the estimation of UCS and E values for gypsum rocks were obtained by the fuzzy type of ANFIS neural networks, and by the model with the feedforward type of neural networks, while results were the worst when the multiple regression model was used [33]. Heidari et al described the use of the MLP and RBF structured neural networks in the estimation of the $E$ value for limestones, dolomites and marls from the Lorestan area in Iran. The following properties were input parameters for the model: density, porosity, velocity of ultrasonic P-waves, and uniaxial compressive strength. Better results were obtained by the model based on MLP architectures and the LevenbergMarquardt algorithm [34]. Based on the study of travertine originating from Iran, Dehghan et al developed models for the estimation of UCS and E values. Laboratory values of porosity, strength index, velocity of ultrasonic P-waves, and Schimdt hardness were used as input data. Models were developed using the principle of generalised regression neural networks (GRNN) and MLP networks trained using the output error back propagartion algorithm [46]. Using the set of 95 tests made for various rock types, Singh et al developed the fuzzy neural model (ANFIS) for estimating the modulus of elasticity, where input parameters were the strength index determined by point load test, density of materials, and water absorption [47]. Manouchehrian et al developed an artificial neural network model for estimating the uniaxial compressive strength of sandstone using petrographic properties [35].

Multiple regression models and neural networks were compared in publications [29, 32-36, 46], and it was concluded that better estimations are made by neural networks. The comparison was based on correlation coefficients involving measured and estimated UCS and E values, and the root mean square error (RMSE). In addition, the MLP architecture proved better than the $\operatorname{RBF}[35,36]$ and the generalised model [46].

\subsection{Estimation based on evolutionary programming}

Genetic algorithms are inspired by the Darwin's theory of natural selection and they even use the corresponding terminology. Here the problems are solved in several steps. In this algorithm, "genes" are various programming instructions. The program that gets more correct results for a number of specified sets obtains a better grade [38]. Baykasoglu et al applied advanced evolutionary programming techniques, namely the multi expression programming (MEP), gene expression programming (GEP), and linear genetic programming (LGP), in order to estimate the UCS of soft limestones in the region of Gaziantep in Turkey. The LGP model of evolutionary programming has proven to be the most efficient of these estimation tools [48]. Ozbeka et al described the use of the GEP model for estimating the UCS of basalt and tuff, and demonstrated that a good correspondence exists between experimentally determined data and results obtained through estimation [49]. Based on genetic programming, Beiki et al developed models for estimating the UCS and E values of carbonate rocks by testing samples collected at the Asmari Formation in Iran [50].

In the future, an increasing number of papers is expected to focus on the comparison of evolutionary programming models with other complex models. For the time being, evolutionary programming models have proven to be better than multiple regression models.

\subsection{Estimation based on regression tree}

The regression tree method, also known as the Decision Tree, enables estimation of numerical variables. It is used to create models that are simple to use and interpret. The parts of the tree are subsets formed of an input set of data according the values of one of predictor variables, so that individual predictor variables are approximately constant in each individual subset. The regression tree branches out depending on questions that can be answered with "yes" or "no" and the set of adjusted values of the variable that is being estimated. Each question establishes whether the predictor meets the requirement. Depending on answers to one question, either the next question is put or it is established that the adjusted value of the answer (variable being estimated) has been achieved. The process stops once the stop criterion has been achieved [51]. The regression tree method has been applied by Tiryaki for estimating the UCS of intact rock material extracted by mechanical excavation. Here, the predictor variables applied 
are the density, NCB cone indent, and scleroscope hardness. He developed the model by testing forty-four samples that had a wide range of rock strength values, from very soft to very hard [52]. One of principal problems with regression trees is that the branching out and calibration of the tree is greatly dependent on the data that are used to develop the model. In other words, if the data are randomly divided into two parts, the results may differ considerably for the same input set.

Various regression tree development procedures aimed at increasing the model accuracy have been developed over time. Some of these methods are the bagging method and the random forest method. In the bagging methods, attempts are made to reduce variability of estimation results by generating a great number of samples from the initial set via sampling with replacement, which is followed by building model on each sample and calculating the average of individual estimations. The bagging can greatly improve the estimation accuracy, but the problem occurs in case a very strong i.e. dominating predictor variable appears, and then the models look similar to one another. This problem is avoided in random forests where a great number of trees is created based on samples chosen from the initial training set by random selection with repetition but, at every branching, the subset of predictors is randomly selected, and a relevant one is then chosen at the branching out step [53]. The models based on regression trees were developed for estimating the UCS values for the mudstone and wackestone type limestones from Croatia, and it was established that the best model was the one in which the random forest method was used for improving the estimation. At that, predictor variables were: density, effective porosity, strength index, Schmidt hardness, and velocity of ultrasonic P-waves [37].

As the regression tree is just being introduced in the UCS estimation, the contribution of this method will better be appreciated only through papers that are yet to be written. A positive aspect is that regression tree can make use of input predictors dependent on each other, and that there are no limitations that are present in multiple regression models.

\section{Discussion}

Based on papers published by other authors, and according to papers published by the authors of this study, including the paper [36] dealing with the UCS and E estimations, and paper [37] dealing with regression trees, the authors of this subject review wish to emphasize that most estimations were made in order to determine the UCS value, and then the Evalue, while other features are much less represented. The simplest way to classify the methods for estimating the UCS and E values is by complexity of procedure and the technology used in the estimation process. Consequently, the estimation methods can be divided into simple and complex ones (Figure 5).

The UCS or E values are estimated using simple methods via diagrams, tables or based on one type of index testing. On the other hand, complex methods make use of several types of test results, which serve as the basis for estimation. Complex computer programs are needed for implementation of these methods.

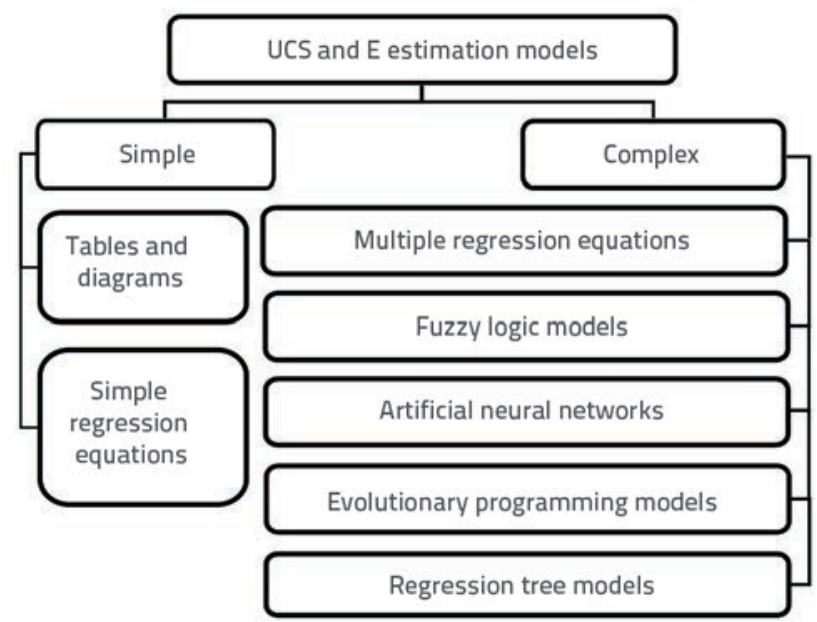

Figure 5. Classification of methods for estimating physicomechanical properties of intact rock material

The UCS and E estimations of intact rock material based on various diagrams, and in case of field identification by handheld accessories, provide rough and general values only, and these estimations are greatly influenced by subjective impressions of the assessor.

Simple regression equations provide relatively good estimation results, but are dependent on the type of rock for which they have been developed and, even within the same rock type, they are not able to cover all property variations. All this has resulted in a great number of equations published in literature, out of which not all can be used, as some are based on tests that have been modified in the meantime. In addition, when these equations are used, care must be taken about the range of values, both with regard to the value being estimated, and to the value on the basis of which the estimation is made.

The comparison of complex UCS and E estimation methods, as developed by numerous researches, shows a certain hierarchy as to success of estimation. Thus, for instance, multiple regression models present the biggest error compared to other complex-method models. However, these models are much simpler for practical application as they do not require the use of complex computer programs. In addition, the modelling using fuzzy logic provides better results in combination with neural networks, compared to the exclusive use of fuzzy models. Models based on neural networks have so far proven to be the most useful tool for the UCS and E estimation. The evolutionary programming models, and the models based on regression tree, have a considerable potential with regard to their estimation capabilities. They have so far proven to be better than multiple regression models.

Although complex estimation models exhibit more favourable success parameters compared to simpler models, these 
simpler methods should not be neglected as estimations are actually made at preliminary design stages. This primarily concerns development of simple regression equations as they are simple to use and are also sufficiently accurate for preliminary stages of design. Although complex methods for estimating the UCS and E are still not widely used in engineering practice as they are developed only by researchers in their research projects, an increasing presence of modelling based on complex methods may be expected in the future due to an increasing availability of commercial program packages (Statistica, Matlab) that enable development of complex models. As researchers are increasingly programming their own applications for such estimations, they will very probably become available through Internet for testing purposes, which will enable even wider application of complex estimation methods. In complex modelling, one should be guided by practical engineering values and avoid the use of input parameters that are difficult to obtain, as their determination requires complicated preparation of samples.

\section{REFERENCES}

[1] Marinos, P., Hoek, E.: Estimating the geotechnical properties of heterogeneous rock masses such as flysch, Bulletin of Engineering Geology and the Environment, 60 (2001), pp. 85-92, http://dx.doi. org/10.1007/s100640000090

[2] Price, D.G.: Engineering Geology: Principles and practice, (ur. De Freitas M.), Springer-Verlag, Berlin Heidelberg, 2009.

[3] Deere, D.U., Miller, R.P.: Engineering classification and index properties for intact rock, Technical Report No. AFNL-TR-65-116. Air Force Weapons Laboratoory, New Mexico, 1966.

[4] Miller, R.P.: Engineering classification and index properties for intact rock, Ph.D Dissertation, University of Illinois, USA, 1965.

[5] Turgrul, A., Zarif, I.H.: Correlation of mineralogical and textural characteristics with engineering properties of selected granitic rocks from Turkey, Engineering Geology 51 (1999), pp 303-317, http://dx.doi.org/10.1016/S0013-7952(98)00071-4

[6] Palchik, V.: Influence of porosity and elastic modulus on uniaxial compressive strength in softbrittle porous sandstones, Rock Mechanics and Rock Engineering, 32 (1999), pp 303-309, http:// dx.doi.org/10.1007/s006030050050

[7] Leite, M.H., Ferland, F.: Determination of Unconfined Compressive Strength and Young's Modulus of Porous Materials by Indentation Tests, Engineering Geology, 59 (2001) 3-4, pp. 267-280.

[8] Lashkaripour, G.R.: Predicting mechanical properties of mudroek from index parameters, Bulletin of Engineering Geology and the Environment, 61 (2002), pp. 73-77, http://dx.doi.org/10.1007/ s100640100116

[9] Palchik, V., Hatzor, Y.H.: Influence of porosity on tensile and compressive strength of porous chalks. Rock Mechanics and Rock Engineering, 37 (2004), pp. 331-341, http://dx.doi.org/10.1007/ s00603-003-0020-1

[10] Tugrul, A.: The effect of weathering on pore geometry and compressive strength of selected rock types from Turkey, Engineering Geology, 75 (2004), pp. 215-227, http://dx.doi. org/10.1016/j.enggeo.2004.05.008

\section{Conclusion}

This paper confirms that the real need for estimation of physicomechanical properties of materials, especially in specific preliminary phases of engineering design, does not imply replacement of testing, but rather that these estimations serve as an extension and verification of some specific data.

Simpler modelling methods should not be neglected in future modelling activities, which namely concerns simple regression equations as they are easy to use and are accurate enough in the preliminary stages of design.

As for complex methods, a particular care should be taken to avoid the use of input parameters in form of physicomechanical properties as their determination requires a complex preparation of samples. It would be advisable to use the values of density, porosity, strength index, and Schmidt hardness, and to compare them with other material properties that can easily be determined, such as the textural and structural description of intact rock material.
[11] D'Andrea, D.V., Fisher, R.L., Fogelson, D.E.: Prediction of compression strength from other rock properties, Colorado School of Mines Quarterly, 59 4b (1964), pp. 623 - 640.

[12] Read, J.R.L., Thornton, P.N., Regan, W.M.: A rational approach to the point load test, Proc. 3rd Australian-New Zealand Geomechanics Conference 2, pp. 35-39, 1980.

[13] ISRM: Suggested method for determining point load strength, International Journal of Rock Mechanics and Mining Sciences \& Geomechanical Abstracts, 22 (1985), pp. 51-60, http://dx.doi. org/10.1016/0148-9062(85)92327-7

[14] Romana, M.: Correlation between uniaxial compressive and pointload (Franklin test) strengths for different rock classes, 9th ISRM Congress, Paris, pp. 673-676, 1999.

[15] Quane, S.L., Russel, J.K.: Rock strength as a metric of welding intensity in pyroclastic deposits, European Journal of Mineralogy, 15 (2003), pp. 855-64, http://dx.doi.org/10.1127/09351221/2003/0015-0855

[16] Tsiambaos, G., Sabatakakis, N.: Considerations on strength of intact sedimentary rocks. Engineering Geology, 72 (2004), pp. 261273, http://dx.doi.org/10.1016/j.enggeo.2003.10.001

[17] Kahraman, S., Gunaydin, O., Fener, M.: The effect of porosity on the relation between uniaxial compressive strength and point load indeks, International Journal of Rock Mechanics \& Mining Sciences, 42 (2005), pp. 584-589, http://dx.doi.org/10.1016/j. ijrmms.2005.02.004

[18] Tziallas, G.P., Tsiambaos, G., Saroglou, H.: Determination of rock strength and deformability of intact rocks, Electronic Journal of Geotechnical Engineering, 14 G (2009), pp 1-12.

[19] Pollak, D.: Utjecaj trošenja karbonatnih stijenskih masa na njihova inženjerskogeološka svojstva, Doktorska disertacija, Rudarskogeološko-naftni fakultet, Zagreb, 2007.

[20] Sachpazis, C. I.: Correlating Schmidt hardness with compressive strength and Young's modulus of carbonate rocks, Bulletin of the International Association of Engineering Geology, 42 (1990), pp. 7584, http://dx.doi.org/10.1007/BF02592622 
[21] Katz, O., Reches, Z., Roegiers, J.C.: Evaluation of mechanical rock properties using a Schmidt hammer, International Journal of Rock Mechanics \& Mining Sciences, 37 (2000), pp 723-728, http://dx.doi. org/10.1016/S1365-1609(00)00004-6

[22] Yilmaz, I., Sendir, H.: Correlation of Schmidt hardness with unconfined compressive strength and Young's modulus in gypsum from Sivas (Turkey), Engineering. Geology, 66 (2002), pp. 211-219, http://dx.doi.org/10.1016/S0013-7952(02)00041-8

[23] Yagiz, S.: Predicting uniaxial compressive strength, modulus of elasticity and index properties of rocks using the Schmidt hammer, Bulletin of Engineering Geology and the Environment, 68 (2009), pp. 55-63, http://dx.doi.org/10.1007/s10064-008-0172-z

[24] Kahraman, S.: Evaluation of simple methods for assessing the uniaxial compressive strength of rock. International Journal of Rock Mechanics and Mining Sciences, 38 (2001), pp. 981-994, http:// dx.doi.org/10.1016/S1365-1609(01)00039-9

[25] Yasar, E., Erdogarg Y.: Correlating sound velocity with the density, compressive strength and Young's modulus of carbonate rocks, International Journal of Rock Mechanics and Mining Sciences, 41 (2004), pp. 871-875, http://dx.doi.org/10.1016/j. ijrmms.2004.01.012

[26] Moradian, Z.A., Behnia, M.: Predicting the uniaxial compressive strength and static young's modulus of intact sedimentary rocks using the ultrasonic test, International Journal of Geomechanics (ASCE), 9 (2009), pp.14-19, http://dx.doi.org/10.1061/ (ASCE)1532-3641(2009)9:1(14)

[27] Au-Yong, C.P., Ali A.S., Ahmad F.: Office building maintenance: Cost prediction model, Građevinar, 65 (2013) 9, pp. 803-809.

[28] Alvarez Grimaa, M., Babuska, R.: Fuzzy model for the prediction of unconfined compressive strength of rock samples, International Journal of Rock Mechanics and Mining Sciences, 36 (1999), pp. 339 349, http://dx.doi.org/10.1016/S0148-9062(99)00007-8

[29] Meulenkamp, F., Alvarez Grima, M.: Application of neural networks for the prediction of the unconfned compressive strength (UCS) from Equotip hardness. International Journal of Rock Mechanics and Mining Sciences \& Geomechanical Abstracts, 36 (1999), pp 29-39, http://dx.doi.org/10.1016/S0148-9062(98)00173-9

[30] Gokceoglu, C., Zorlu, K.: A fuzzy model to predict the uniaxial compressive strength and the modulus of elasticity of aproblematic rock, Engineering Applications of Artificial Intelligence, 17 (2004), pp. 61-72, http://dx.doi.org/10.1016/j.engappai.2003.11.006

[31] Karakus, M., Tutmez, B.: Fuzzy and Multiple Regression Modelling for Evaluation of Intact Rock Strength Based on Point Load, Schmidt Hammer and Sonic Velocity, Rock Mechanics and Rock Engineering, 39 (2006) 1, pp. 45-57.

[32] Kahraman, S., Gunaydin, O., Alber, M., Fener, M.: Evaluating the strength and deformability properties of Misis fault breccia using artificial neural networks, Expert Systems with Applications, 36 (2008) 3, pp. 6874-6878.

[33] Yilmaz, I., Yuksek, G.: Prediction of the strength and elasticity modulus of gypsum using multiple regression, ANN, and ANFIS models, International Journal of Rock Mechanics and Mining Sciences, 46 (2008) 4, pp. 803-810.

[34] Heidari, M., Khanlari, G.R., Momeni, A.A.: Prediction of elastic modulus of intact rocks using artificial neural networks and nonlinear regression methods, Australian Journal of Basic and Applied Sciences, 4 (2010) 12, pp. 5869-5879.
[35] Manouchehrian, A., Sharifzadeh, M., Moghadam, R.H.: Application of artificial neural networks and multivariate statistics to estimate UCS using textural characteristics, International Journal of Mining Science and Technology, 22 (2012), pp. 229-236, http://dx.doi. org/10.1016/j.jimst.2011.08.013

[36] Briševac, Z.: Model međuovisnosti fizikalno-mehaničkih značajki karbonatnih stijena, Doktorski rad, Rudarsko-geološko-naftni fakultet, Zagreb, 2012.

[37] Briševac, Z., Špoljarić, D., Gulam, V.: Estimation of uniaxial compressive strength based on regression tree models., Rudarskogeološko-naftni zbornik, 29 (2014), pp 39-47.

[38] Dvornik, J.: Numeričke, simboličke i heurističke metode, GRAEEVINAR, 55 (2003) 10, pp. 575-582.

[39] Cerić, A., Marić, T.: Određivanje prvenstva pri upravljanju rizicima građevinskih projekata, GRAĐEVINAR, 63 (2011) 3, pp. 265-271.

[40] Žagar, Z., Janjuš, G.: Primjena neuralnih mreža u projektiranju drvenih konstrukcija, GRAEEVINAR, 54 (2002) 10, pp. 577-583.

[41] Vouk, D., Malus, D., Carević, D.: Neuralne mreže i njihova primjena u vodnom gospodarstvu, GRAEEVINAR, 63 (2011) 6, pp. 547-554.

[42] Farrokhzad, F., Choobbasti, A.J., Barari, A.: Determination of liquefaction potential using artificial neural networks, GRAEEVINAR ,63 (2011) 9, pp. 837-845.

[43] Tayfur, G., Egeli, I.: Railway embankment design based on neural networks, GRAEEVINAR, 65 (2013) 4, pp. 319-330.

[44] Gupta, M.M., Rao, D.H.: Neuro-Control Systems, Theory and Applications, IEEE Press, New York, 1994.

[45] Sonmeza, H., Gokceoglua, C., Nefeslioglub, H.A., Kayabasi, A.: Estimation of rock modulus: For intact rocks with an artificial neural network and for rock masses with a new empirical equation, International Journal of Rock Mechanics \& Mining Sciences, 43(2006), pp. 224-235, http://dx.doi.org/10.1016/j.ijrmms.2005.06.007

[46] Dehghan, S., Sattari, G., Chehreh, C.S., Aliabadi, M.A.: Prediction of uniaxial compressive strength and modulus of elasticity for Travertine samples using regression and artificial neural Networks, Mining Science and Technology, 20 (2010), pp. 41-46, http://dx.doi.org/10.1016/s1674-5264(09)60158-7

[47] Singh, R., Kainthola, A., Singh, T. N.: Estimation of elastic constant of rocks using an ANFIS approach, Applied Soft Computing, 12 (2012), pp. 40-45, http://dx.doi.org/10.1016/j.asoc.2011.09.010

[48] Baykasoglu, A., Gullu H., Canakcı, H., Ozbakır, L.: Prediction of compressive and tensile strength of limestone via genetic programming, Expert Systems with Applications, 35 (2008), pp. 111-123, http://dx.doi.org/10.1016/j.eswa.2007.06.006.

[49] Ozbeka, A., Unsal, M., Dikec, A.: Estimating uniaxial compressive strength of rocks using genetic expression programming, Journal of Rock Mechanics and Geotechnical Engineering, (2013) 5, pp. 325329, http://dx.doi.org/10.1016/j.jrmge.2013.05.006

[50] Beiki, M., Majdi, A., Givshad, A.D.: Application of Genetic Programming to predict the uniaxial compressive strength and elastic modulus of carbonate rocks, International Journal of Rock Mechanics \& Mining Sciences, 63 (2013), pp. 159-169, http://dx.doi. org/10.1016/j.jirmms.2013.08.004

[51] Breiman, L., Friedman, J.H., Olshen, R.A., Stone, C.J.: Classification and Regression Trees, Chapman and Hall/CRC, 1984.

[52] Tiryaki, B.: Predicting intact rock strength for mechanical excavation using multivariate statistics, artificial neural networks and regression trees, Engineering Geology, 99 (2008), pp. 51-60, http://dx.doi.org/10.1016/j.enggeo.2008.02.003

[53] James, G., Witten, D., Hastie, T., Tibshirani, R.: An Intorduction to Statistical Learning with Applications in R, Springer, New York, 2014. 